\title{
Library Resources for Classical Studies
}

A MERICAN RESEARCH LIBRARIES have a history of continuous growth and development. Today there are five libraries in the United States with over three million volumes each-the Library of Congress, Harvard, the New York Public, Yale, and the University of Illinois-and another thirty-four whose holdings range from one to three million volumes. ${ }^{1}$ Among the vast quantities of volumes held by these and other libraries are special collections and notable materials in every subject area, but. knowledge of these resources is far from complete. Although the number of bibliographies, guides to resources, check lists, and other tools has multiplied greatly, the holdings of many institutions remain to be described, ${ }^{2}$ and the total national picture is still only partially complete. It is obvious that scholars in every field and librarians alike depend on bibliographical aids to assist them in locating and utilizing fully the country's research resources. From 1946 through 1954 there were 266 doctoral dissertations prepared in classical literature and history; ${ }^{3}$ certainly they required intensive use of many library materials. The objective of this paper is to describe the library resources for clas-

${ }^{1}$ American Library Directory (21st ed.; New York: Bowker, 1957).

${ }^{2}$ Robert B. Downs, American Library Resources, A Bibliographical Guide (Chicago: ALA, 1951), p if. ${ }^{3}$ William V. Jackson, "The Distribution of Doctorates in Postwar Years," Journal of Higher Education, XXVIII (1957), 41-44.

Dr. Jackson is Associate Professor of Library Science, University of Illinois. This paper was presented at the Illinois Classical Conference, Chicago, February 19-21, 1959. sical studies that are available in American research libraries. (Although the term "classical studies" is used here in a wide sense, it necessarily emphasizes Greek and Latin literature.) It attempts to synthesize the information available, for the most part, in published guides and descriptions, but for this very reason can make no pretense at completeness. This report consists of two parts which complement each other. The first of them presents general descriptions of the holdings of a number of major libraries, while the second section deals with the special collections of books by and about individual authors. The advantages of bringing together the comments on holdings of each author seemed to outweigh the disadvantages of separating them from the remarks on the library to which they belong.

\section{RESOURCES OF MAJOR LIBRARIES}

What institutions have notable resources in the field of classical studies? As one might expect, the largest concentration of them exists in the older, larger, and more developed libraries along the east coast. This survey therefore begins there, proceeding later to the Midwest and Far West.

Harvard. At Harvard is one of the country's notable classical collections, comprising over 64,000 volumes. ${ }^{4} \mathrm{Nu}$ merous first editions are among them, together with a number of manuscripts, chiefly from the fourteenth and fifteenth centuries. In addition, Harvard has practically all the chief critical editions and commentaries of classical authors. Par-

4 "The Harvard University Library: A Graphic Summary," Harvard Library Bulletin, IX (1955), 84. 
ticularly well represented are Homer and Cicero, each with over one thousand volumes, Aesop, Boethius, Caesar, Horace, Plato, Plautus, Theocritus, and Virgil. Sets of practically all the principal periodicals dealing with classical and archaeological subjects strengthen these resources, as do a large number of programs and dissertations of German universities. 5

A special reading room, the Herbert Weir Smyth Classical Library, houses a seven-thousand-volume working collection of college texts of the most important authors, standard works like the Corpus Inscriptionum Latinarum and the Inscriptiones Graecae, and a number of periodicals. An important palaeographical collection of over six hundred volumes occupies adjacent quarters in the Widener Building. ${ }^{6}$

Other classifications in the Harvard Library add materially to these resources. There are extensive holdings relating to the private lives of Greeks and Romans and to the archaeology of Greece and Rome. In addition to an important collection in ancient history, there are over a thousand volumes on the catacombs and Christian antiquities of Rome and Italy. Widener does not have a great many books on Roman law because the Law School's extensive holdings make duplication unnecessary. ${ }^{7}$

Yale. Scholars find valuable material in classics at the Yale University Library, but they can be only partially described here because the Library has not yet published a guide to its resources. In 1935 Yale received two groups of particular importance: the Ionides Collection of Greek classics, a gift from Chaun-

\footnotetext{
${ }^{5}$ A. C. Potter, Library of Harvard University (4th ed.; Cambridge, Mass.: Harvard University Press, 1934), pp. 66-68; Garrett Mattingly, "The Lawrence Bequest," Harvard Library Notes, II, No. 14 (March 1925), $29 \mathrm{f}$

1925), 29f. $\mathrm{Marjorie} P$. Wood, "The Herbert Weir Smyth Collection," Harvard Library Notes, III, No. 28 (May 1938), 145f.; Herbert Bloch, "The Classical Libraries at Harvard," Harvard Library Bulletin, IV (1950), 399-403; "Smyth Classical Library," Harvard Alumni Bulletin, XLIV (1942), $526 \mathrm{f}$

Bulletin, XLIV (194.
}

cey B. Tinker as a memorial to his father, the Reverend Anson Phelps Tinker, and the Marston Greek Classics. The former comprises 165 items in 236 volumes, the latter 90 items. The Ionides Collection includes a number of first editions of Greek writers - e.g., Homer, Aristophanes, Euripides, Plutarch, Lucian, Pindar, Aeschylus, Euclid, Ptolemy, and Archimedes-which combine with first editions of other authors to place Yale's holdings among those of first rank. There is a choice group of early grammars, among them the earliest book in the collection (1483), the Graeco-Latin vocabulary compiled by the Carmelite monk generally known as Crastonus. ${ }^{8}$ The Marston items, nearly all printed before 1600 , embrace a number of Aldines: the first Plutarch Moralia (1509), the first Euripides (1503), and the first Aeschylus (1518). ${ }^{9}$ Some years after these gifts Yale reported the acquisition of several hundred additional titles of early editions of Greek and Latin writers. ${ }^{10}$ One might also note that the Library owns a long line of editions of Pindar ${ }^{11}$ and no less that eleven copies of Baskerville's Virgil.12

In 1944 Mr. and Mrs. David Wagstaff enriched Yale's resources with twentytwo manuscripts of classical and medieval Latin authors, ranging in date from the thirteenth to the end of the fifteenth century. Seven Cicero manuscripts form the largest group, but Virgil, Ovid, Seneca, Terence, Boethius, Valerius Maximus, and Caesar are also present. ${ }^{13}$ In

\footnotetext{
8Austin M. Harmon, "The Ionides Collection of Greek Classics," Yale University Library Gazette, X (1935), 1.5.

"Thomas E. Marston, "The Marston Greek Classics," Yale University Library Gazette, X (1935), 5-7.

${ }^{10} \mathrm{John}$ Van Male, "Notable Materials Added to American Libraries, 1941-1942," Library Quarterly, XIV (1944), 138.

${ }^{11}$ Marston, op. cit., p. 7

${ }^{12}$ Allen T. Hazen, "Baskerville's Virgil," Yale University Library Gazette, XI (1937), 90-93; cf. Rebecca Dutton Townsend and Margaret Currier, "A Selection of Baskerville Imprints in the Yale University Library" in Papers in Honor of Andrew Keogh (New Haven: Privately printed, 1938), pp. 285-97.

${ }^{13}$ Edmund T. Silk, "The Wagstaff Collection of Classical and Mediaeval Manuscripts," Yale Univer. sity Library Gazette, XIX (1944), 1-9.
} 
addition to these items, Yale has two manuscripts of Boethius' Consolatio Philosophiae; ${ }^{14}$ although both date from the fifteenth century, one calls for special comment because it is bound as a "girdle book," that is, a small volume designed to hang like a purse from the owner's belt. ${ }^{15}$ It is not necessary to do more than mention three Tacitus manuscripts, because they receive fuller comment later.

Yale acquired in 1896 the library of Professor Ernest Curtius of Berlin, consisting of about 3,500 volumes and the same number of pamphlets. Especially rich in the field of classical archaeology, it added to the library's resources in this area. ${ }^{16}$

New York Public Library. Although the New York Public Library does not stress classical literature, its holdings may be viewed as a good working collection which contains some rarities. There are about 5,500 volumes of Greek literature (including medieval and modern) and about 4,500 of Latin. Present are histories, critical works, and various standard editions of authors, both in original languages and in translation, as are various early editions; literary and philological periodicals constitute an important part of the collection. An interesting special feature is a small group of Greek and Latin classics in Spanish. Material classified elsewhere substantially enhances these resources. In philology, there are complete files of most of the philological journals; in history, editions of the classical historians; in classical folklore, an extensive and rich collec-

${ }^{14}$ Silk, "A New Manuscript of Boethius' Consolatio," Yale University Library Gazette, XVIII (1944), $46 \mathrm{f}$ ${ }^{15}$ Silk, "The Yale 'Girdle-Book' of Boethius," Yale University Library Gazette, XVII (1942), 1-5 ${ }^{16}$ Yale University, Report of the Librarian, $J u l y$ 1950-June 1951 (Bulletin of Yale University, Ser. 47. No. 14 (1951), p. 58f.; Yale University Library, An Exhibition of Manuscripts and Books Illustrating the Transmission of the Classics from Ancient Times to 1536 ([New Haven], 1947). tion; and in classical archaeology, many items. ${ }^{17}$

Columbia. At Columbia University will be found practically everything of value in Greek and Latin literature published in recent decades. Although the collection of earlier works contains some lacunae, it is also excellent. ${ }^{18}$ Especially notable are the library's holdings of early editions of works in the classics (among them Greek grammars of the fifteenth and sixteenth centuries and the Aldine editions of Homer and Herodotus $^{19}$ ) and of material in the field of antiquities, paleography, and epigraphy. There is a special epigraphical library with a collection of original inscriptions -mostly in Latin-and of squeezes; a papyrus division possesses 600 to 700 original Greek papyri, largely unpublished, as well as a practically complete papyrological library, making it one of the best in the Western Hemisphere. ${ }^{20}$

Princeton. Still another university library with important resources in classics is Princeton. It has numerous examples of early editions of Pliny, Terence, Plautus, Ovid, Aristotle, Homer, and Euripides. ${ }^{21}$ One might also note two special features: a collection of about forty thousand German dissertations on classical subjects, and the inclusion of a number of classical works in the McKenzie Fable Collection. Among these are Batrachomyomachia (Battle of Frogs and Mice), long ascribed to Homer, accompanied by the Galeomyomachia (Battle of Cats and Mice) in editions of

\footnotetext{
${ }^{17}$ Karl Brown, $A$ Guide to the Reference Collections of the New York Public Library (New York: New York Public Library, 1941), p. 132: Downs, Resources of New York City Libraries (Chicago: ALA, 1942), p. 198.

${ }^{18}$ Downs, Resources of New York City Libraries, p. 197.

${ }^{19}$ George A. Plimpton, "Greek Manuscripts and Early Printed Books in the Plimpton Library," Transactions and Proceedings of the American Philo. logical Association, LXV (1934), 260-70.

${ }^{20}$ Downs, Resources of New York City Libraries, p. 197; William L. Westermann, "The Columbia Collection of Greek Papyri," Columbia University Quarlection of Greek Papyri," Col
terly, XXIII (1931), 276-85.

terly, XXIII (1931), 276-85. Italy, With Special Reference to the Classics, 1469.
} 1517 ([Princeton], 1940). 
Aesop printed at Basle, 1541; Lyon, 1582; and Paris, 1585. In the same group the reader will find a number of the sixteenth-century editions of fables derived from Aesop through Romulus. ${ }^{22}$

Pennsylvania. The University of Pennsylvania's classical collections constitute a notable assemblage of resources. For Greek one finds numerous early editions of authors, many translations, and a group of dictionaries, grammars, handbooks, commentaries, and other helps. Greatest strength appears in Aristotle, Plato, the dramatists, Plutarch, and Homer and the epic. The library is also strong in papyrology, epigraphy, and archaeology. Complete sets of learned journals in the field, some of them going back to the early nineteenth century, further enhance the collection's value.

For Latin this library contains practically all the editions, both text and annotated, of all the Latin authors that are ever read or referred to. Particularly good is the group of older editions of authors, due in part to the purchase of the 20,000-volume library of Professor E. L. von Leutsch of the University of Goettingen in $1890 .{ }^{23}$ A group of early French translations of the classics has been acquired to show their influence, and among them will be found the first edition of Remi Belleau's version of the odes of Anacreon (Paris, 1556) and early editions of translations of Homer, Caesar and Cicero. ${ }^{24}$ Complete sets of American, English, and foreign scholarly periodicals add to the collection, but holdings in Latin epigraphy and Roman archaeology are not so strong.

Library of Congress. It is especially difficult to evaluate the holdings of the Library of Congress, due to the lack of

\footnotetext{
22Kenneth McKenzie, "Some Remarks on a Fable Collection," Princeton University Library Chronicle, V (1943), 137-49.

${ }^{23}$ Bibliographic Planning Committee of Philadelphia, A Faculty Survey of the University of Pennsylvania Libraries (Philadelphia: University of Pennsylvania Press, 1940), pp. 90-93.

24John Alden, "Some Recent Additions to the Rare Book Collection," University of Pennsylvania Library Book Collection," University
Chronicle, XV (1948), 59.
}

a complete guide to its resources. However, they are undoubtedly superior to those of most other American libraries. For classical literary and philosophical writings the scholar has at his disposal not only the standard editions and reference works, but also commentaries, critical works, and a number of rare early recensions. Also worthy of mention is a sizeable collection of photostatic copies of manuscripts of classical writings, particularly the works of Aristotle, Terence, and Ovid. ${ }^{25}$ Many early editions of classical literature are present in the Vollbehr collection of incunabula, comprising 3,000 items and acquired in 1930.26

North Carolina. Strong resources in classics are available at the University of North Carolina. Most notable holdings fall into the fields of classical bibliography, Latin and Greek literature, ancient history and civilization, papyrology, and epigraphy; there is also material in paleography, religion and mythology, classical linguistics, and numismatics. General classical periodicals, reference materials, and bibliographies are quite complete, while for individual authors the library possesses all important individual editions, critical and annotated, as well as such sets as the Loeb Classical Library, Bibliotheca Teubneriana, and the Oxford Classical Texts. A comprehensive collection of recent works and of most of the older standard volumes covers the field of Greek drama, and the same is true of Homer; in Latin there are notable materials devoted to Cicero, Catullus, Virgil, Horace, Livy, and Tacitus. In paleography the scholar may consult standard works and facsimiles of manuscripts, including microfilms or photostats of 250 treatises from about

${ }^{25} \mathrm{U}$. S. Library of Congress, Reference Department, A Report on Certain Collections in the Library of Congress (Washington, 1942), pp. 5, 18.

${ }^{20}$ U. S. Library of Congress, Exhibit of Books Printed During the $X V$ th Century and Known as Incunabula, Selected From the Vollbehr Collection Pur. chased bv Act of Congress, 1930 (Washington: Govt. chased bv Act of Congress, 1936
Print. Off., 1930), pp. 26-33. 
160 Latin manuscripts; in papyrology the Library has approximately one hundred volumes; in archaeology, a very good representation of the chief works in the field, including important books on Greek and Roman art. ${ }^{27}$

Illinois. Private libraries of two German scholars have aided in the development of the classics collection at the University of Illinois. The University purchased the first of these in 1907 from Professor Wilhelm Dittenberger of Halle University; it comprised 5,600 volumes and pamphlets. The second came from Professor Johannes Vahler of Vienna and Berlin; it was purchased in 1913 and numbered about 10,000 volumes and 15,000 pamphlets. ${ }^{28}$ Total holdings of classical literatures at Illinois now amount to about 61,000 volumes, to which should be added thousands of volumes classified in history and in other related subjects. ${ }^{29}$

A strong periodical collection encompasses practically all the really important journals in the field-those devoted to particular phases of classical studies as well as those of wide scope. Of over 300 titles there are complete or very nearly complete files of more than 260 . One might cite as examples the first true journal published in the field, $M$ iscellaneae Observationes Criticae Novae, founded in 1723; Jahrbücher für Philologie (1826-1943); Revue de Philologie; and Journal of Philology. In all, the serial holdings total over 7,000 volumes. In epigraphy scholars at Illinois have at their disposal the handbooks, specialized dictionaries and manuals of epigraphic technique, and every known major collection of texts; although the important journals are available, coverage of the regional journals of more or less miscellaneous content listed in Annee epi-

${ }^{27}$ Charles E. Rush (ed.), Library Resources of the University of North Carolina (University of North Carolina Sesquicentennial Publication; Chapel Hill: University of North Carolina Press 1945), p 129-35. 28Illinois University Library, Staff Manual (Urbana: ${ }^{28}$ Illinois University Library, Staff Manual (Urban
University of Illinois Library, 1947), p. 114f.

${ }^{20} \mathrm{Jackson}$, Studies in Library Resources (Cham. paign, IIl.: Distributed by the Illini Union Bookstore, 1958), Table 1, p. 44. graphique does not approach completeness. Greek epigraphy is probably the best covered. In papyrology Illinois owns all of the tools and special reference works; the oldest and most famous collection, the Neapolitan Academy's Collectiones Herculanensium Voluminum (1793-1876); and complete sets of the more recent collections. ${ }^{30}$

Other areas in which resources at Illinois are strong include Greek and Latin grammar and lexicography, while medieval Latin, patristics, Byzantine, and modern Greek are fairly well represented. The collection has excellent holdings of the critical texts and criticism of Greek and Latin authors, while numerous early editions are available. Individual authors well represented (including in some cases photostats and collections of manuscripts) might be listed: Aesop, Apuleius, Avianus, Epictetus, Jerome, Plutarch, Suetonius, and Terence. $^{31}$

Northwestern. The first important gift to the Northwestern University Library made possible the purchase of the library of Johann Schulze, a member of the Prussian Ministry of Public Instruction. Since the greatest strength of this collection lay in the classics, it formed the foundation of the Library's resources in this area. It encompassed 11,246 volumes and about 9,000 pamphlets (chiefly dissertations from German universities), among them many of the best nineteenth century editions of classical authors. ${ }^{32}$ Northwestern now possesses over 12,000 books classified as Greek and Latin literature, 33 a number which will be significantly augmented by means of a recent gift of $\$ 6,000$ from Arthur Williams. ${ }^{34}$

\footnotetext{
${ }^{30}$ Information furnished by Miss Edith C. Jones, classics librarian, University of Illinois.

${ }^{31}$ Illinois University Library, loc. cit.

${ }^{32}$ Arthur $H$. Wilde, Northwestern University, $A$ History, 1855-1905 (New York: University Publishing Society, 1905), III, $197 \mathrm{f}$.

${ }^{3}$ Tackson, Studies in Library Resources, Table III, p. 48 .

${ }^{34}$ Northwestern Library News, XII (January 31 , 1958), 1 .
} 
California (Berkeley). For its holdings in classics the University of California at Berkeley has aimed at acquiring all available material in English, together with the desirable and significant works in major and minor European languages. Among the Greek authors its holdings are excellent for Homer, Plato, the historians, and the leading dramatists. The Latin collection, on the whole, may be considered an admirable one, with very good holdings on Cicero, Livy, Seneca, Lucretius, Virgil, Ovid, Catullus, Propertius, and Tibullus. ${ }^{35}$ Present in the Moffitt gift, which the library received in 1956, are incunabula of Cicero, Virgil (including the editio princeps of the Bucolica, 1468), Euclid, Lucretius, Plutarch, Herodotus, and Seneca. ${ }^{36}$ A private library acquired some years ago contained early editions of classical authors from many European countries. ${ }^{37}$ In 1941 the Library reported the addition of a papyrus collection of major importance. It contains mainly Greek papyri written in the period 250-30 B.C., including 1,093 published in the Tebtunis papyri series. These holdings throw light upon a period for which there is comparatively little papyrus available. ${ }^{38}$

Other Libraries. This paper could not describe the holdings of all American libraries with significant collections in the field of classical studies, because, as was already pointed out, not all of them have published guides to their resources or otherwise described their holdings. However, it seems appropriate to call attention to some libraries not discussed above. Three tools which aid in identifying them are an article on leading collections in American libraries, ${ }^{39}$ the re-

\footnotetext{
${ }^{35}$ Fulmer Mood, A Survey of the Library Resources of the University of California (Berkeley: University of California General Library, 1950), pp. 201-204.

36 "Moffitt Gift," CU News, XI (May 23, 1956), 4.

37 Downs, "Notable Materials Added to American Libraries, 1940-41," Library Quarterly, XII (1942), $184 f$.

${ }^{38}$ Downs, "Notable Materials Added to American Libraries, 1939-1940," Library Quarterly, XI (1941), 266.

${ }^{39}$ Downs, "Leading American Library Collections," Library Quarterly, XII (1942), 459.
}

cent publication Subject Collections, ${ }^{40}$ and the Index to Special Collections maintained at the Library of Congress. According to these tools libraries belonging to the group of institutions possessing significant resources for classical studies include the Boston Public and those of the following universities: Chicago, Cincinnati, Cornell, Indiana, Johns Hopkins, Michigan, ${ }^{41}$ New York, Stanford, Texas, Virginia, and the Joint University Libraries in Nashville.

For five of them statistics of holdings, at least, are available. Virginia has over 9,000 volumes and a pamphlet collection of about the same size; the Joint University Libraries, about 5,000 volumes; and Texas, 6,788 volumes-but these totals date from 1938. ${ }^{42}$ More recent are the figures of 67,000 for Chicago ${ }^{43}$ and 66,000 for Cincinnati; ${ }^{44}$ for the latter a partial catalog was published some years ago. ${ }^{45}$

It is well to bear in mind that the above statistics and others cited in this article are not fully comparable for several reasons. The subject categories used by different libraries vary in breadth; a single class in one institution may encompass what other libraries place in several groups. Moreover, libraries use a variety of classification schemes with different divisions of knowledge. ${ }^{46}$ Finally, "there is little uniformity at present in the methods used for measuring library holdings." 47 Comparisons made on the basis of quantity do not, of course, imply any judgment as to quality.

${ }^{40}$ Lee Ash, Subject Collections (New York: Bowker, 1958), passim.

${ }^{41}$ Henry A. Sanders (ed.), Latin Papyri in the University of Michigan Collection, (University of Michigan Studies, Humanistic Series, Vol. XLVIII Michigan Papyri, Vol VII; Ann Arbor: University of Michigan Press, 1947).

42Downs (ed), Resources of Southern Libraries (Chicago: ALA, 1938), pp. 103-105.

${ }^{43}$ Chicago University Library, Introduction to the University of Chicago Library (Chicago, 1953), p. 18. ${ }^{44}$ Ash, op. cit., p. 105.

45[John M. Burnam] "Summary Catalogue of a Part of the Library of John M. Burnam," University of Cincinnati University Studies, Ser. 2, II (September-October 1906)

${ }^{40}$ Jackson, Studies in Library Resources, pp. 45-47 "Downs, "Research in Problems of Resources," Library Trends, VI (1957), 155. 
Special Collections of Individual Authors

Aeschylus. The collection of Aeschylus at Harvard numbers over $\mathbf{5 5 0}$ volumes and, in addition, the library has photographic copies, either in whole or in part, of many of the 120 manuscripts of Aeschylus listed in Smyth's catalog. ${ }^{48}$

Aesop. Several American libraries hold special collections of Aesop material. In addition to several hundred volumes in its classics collection, Harvard has a group of Aesopian imitations-tracts published in England in the eighteenth century,49 while the McKenzie Fable Collection at Princeton also has such material. ${ }^{50}$

At the Library of Congress one finds the largest and finest copy of the first edition (1480) of Aesop and a Latin 1487 edition. Although this collection does not include the first edition in English (a 1484 Caxton), mention might be made of Aesop in German and Italian incunabula, as well as of later editions. ${ }^{51}$

Aristophanes. In 1919 the family of Professor John William White gave his Aristophanes collection to the Harvard Library. It comprised 600 volumes and 450 pamphlets. ${ }^{52}$

Aristotle. One of the country's notable collections of Aristotle is found at the University of Pennsylvania Library. It includes not only the standard texts of his writing and of the ancient commentators, but also a very extensive number of monographs. In 1938 Dr. Charles W. Burr, who had been enlarging the Library's holdings in this area, presented 500 special items and monographs dealing with Aristotle. For the most part they consist of doctoral dissertations, university programs, and other pamphlets dealing with special topics; about

\footnotetext{
${ }^{48}$ Herbert Weir Smyth, "Catalogue of the Manuscripts of Aeschylus," Harvard Studies in Classical Philology, XLIV (1933), 1-62.

49 "Aesopian Imitations," Harvard Library Notes, I, No. 11 (May 1923), 242-48.

${ }^{50} \mathrm{McKenzie}$. loc. cit.

"Eleanor Weakley Nolen, "Aesops in the Library of Congress," Horn Book, XIV (1938), 311-15.

52Potter, op. cit., p. 67.
}

one-fourth of them treat of philosophy; seventy-two are concerned with the $\mathrm{Po}$ etics and fifty-eight with the Politics, while the remainder are scattered over the whole Aristotelian field. In recent years the collection has been strengthened by the addition of unpublished manuscripts and some of the less common early printed translations and commentaries (e.g., the first French translations of the Ethica, published in Paris in 1488 and not previously reported by any library in the United States). ${ }^{53}$

Indiana University Library possesses a collection of more than three hundred commentaries on Aristotle, thirty-four of which are in manuscript form. This material dates from the fifteenth through the eighteenth centuries with emphasis on the period 1500-1699.

Avianus. The University of Illinois Library has built up a notable collection of Avianus, comprising not only published books and pamphlets but also photostats and manuscripts. Oldfather lists and locates copies of some items not found in Leopold Hervieux's Les Fabulistes Latins. ${ }^{54}$

Epictetus. The University of Illinois Library has assembled an extensive collection of Epictetus material. Oldfather's bibliography and its supplement locate items in this institution and in a number of other American and foreign libraries, thus facilitating greatly the task of anyone working in this area. ${ }^{55}$

Herodotus. Special collections of $\mathrm{He}$ rodotus do not appear in the published guides to resources. However, in 1940 Harvard was given a collection of early editions. ${ }^{56}$

Juvenal. Yale has an extensive group

\footnotetext{
${ }^{53}$ William N. Bates, "A Scholar's Library on Aristotle," University of Pennsylvania Library Chronicle, VI (1938), 16-18.

${ }^{54}$ W. A. Oldfather, "Bibliographic Notes on the Fables of Avianus,"' Papers of the Bibliographical Society of America, XV (1921), 61-72.

${ }^{55}$ Oldfather, Contributions Toward a Bibliography of Epictetus ([Urbana]: University of Illinois, 1927); Marian Harman (ed.), Supplement (Urbana: UniMarian Harman (ed.), Supplem

"Downs, "Notable Materials Added to American Libraries, 1940-1941," p. 184.
} 
of Juvenal material, the gift of Thomas E. Marston. It comprised originally 13 manuscripts and 286 volumes, including 32 incunabula, editions of the text, commentaries, whether printed separately or with the text, translations, and some miscellaneous volumes containing excerpts or quotations from Juvenal. The earliest item is a fragment of a late twelfth-century manuscript, while the earliest printed book bears the date of 1470 . Of the 50 known editions of Juvenal which appeared between 1470 and 1500 the collection contains copies of 18 , while 47 of a total of more than 150 editions of the sixteenth century are present. The latter group includes the three Aldines and the three counterfeit Aldines printed at Lyons. Although the collection does not have the first printing of Juvenal in England (done in conjunction with Norton's Horace in 1574), it does contain the first four separate editions printed in England. Additional copies come from later centuries, down to the second edition of A. E. Housman (Cambridge, 1931), and from Housman's library four recent editions with his bookplate and a copy of Mayor's first edition, 1853, interleaved and with some manuscript notes. ${ }^{57}$

Marcus Aurelius. In 1926 William Smith Mason gave Yale 494 volumes of works by and about Marcus Aurelius. The collection includes editions of the Greek text as well as many translations into various languages. ${ }^{58}$

Persius. Shortly before the death of Professor Morris Hicky in 1910 the Harvard Library received as a gift his collection of Persius. At that time the gathering contained some 295 editions, 213 translations, and about 125 commentaries and critical works. Daniel B. Fearing added several rare editions to it, and Harvard acquires other items as

${ }^{57} \mathrm{G}$. L. Hendrickson, "The Marston Juvenals," Yale University Library Gazette, XII (1938), 71-88; Yale University, Report of the Librarian, July 1950June 1951 p. 69.

${ }^{58}$ Yale University, Report of the Librarian, July 1950-June 1951, p. 74. they become available. The published catalog locates copies at other libraries as well. ${ }^{59}$

Philo Judaeus. Probably the best place in the world for research on Philo Judaeus is the Yale Library, as a result of the generosity of Howard L. Goodhart in 1950. His gift of 228 volumes of monographs, 86 volumes of periodicals, and 27 volumes of photostats represented items not already in the Yale collections. Among them are fifteen editions of the Greek text of Philo's works, ten editions of Latin translations, and a number of translations into modern European languages. Some interesting association copies came from the library of F. C. Conybeare, the great Oxford authority on Philo. As missing items come on the market they are added to the collection. ${ }^{60}$

Seneca. The Boston Public Library has a distinguished group of fine editions and translations of the works of Seneca, the earliest of them being the Omnia Opera (Venice: Bernadinus de Choris, 1492). Two other incunabula present are the Tragoediae (Venice: Lazarus de Soardis, 1492) and Formula Vitae Honestae (Paris: Wolfgang Hopyl, date unknown). There are several distinguished seventeenth-century editions. The Library's Ticknor Collection contains a notable group of Spanish translations of Seneca, some of them rare and early editions. The 1500 Proverbios de Seneca is the oldest of them, while other interesting items are the scarce second edition of Los $V$. Libros de Séneca (1510) and the Flores printed by Christopher Plantin at Antwerp in 1555 .

A wealth of source material useful for studying Seneca's influence on English literature is found in the Library's Barton Collection. Here are not only Ar-

\footnotetext{
50 Potter, op. cit., p. 67; Morris H. Morgan, $A$ Bibliography of Persius, (Harvard University Library Bibliographical Contributions, No. 58; Cambridge, Mass.: Harvard University Library, 1909).

${ }^{\circ}$ Erwin R. Goodenough, "A Collection of Philo Judaeus," Yale University Library Gazette, XXV $(1951), 155 \mathrm{f}$.
} 
thur Golding's version of De Beneficiis, the first authentic work of Seneca to be translated completely into English, but also the well known group of translations by various hands entitled Seneca His Tenne Tragedies Translated Into Englysh (London: Thomas Marsh, 1581). ${ }^{61}$

Tacitus. At Yale there is a distinguished collection of Tacitus, of which a thousand volumes were given to the library in 1932 by Clarence W. Mendell. One-half of this group consisted of editions and translations, while the remainder represented commentaries on the histories. ${ }^{62}$ Yale's resources include three manuscripts, of which one was originally owned by Matthias Corvinus, King of Hungary (1458-90). It contains the last six books of the Annals and the five books of the Histories. ${ }^{63}$ The second copy is closely related in text to the first, ${ }^{64}$ while the third is a fifteenth-century manuscript of Books XI-XXI, containing a coat of arms which appears to be that of Alfonso II, Duke of Calabria (1448-95); photostatic copies of some of the less important manuscripts are also available. ${ }^{65}$

Yale's book holdings begin with the editio princeps (Venice: Wendelin de Spira, ca. 1470). "Of perhaps thirty-four editions in the fifteenth and sixteenth centuries, the Library possesses twentyone, including all the important ones. For example, we now have the first printed edition, the first complete edition, the first edited by Beatus, the first Juntine, the first Aldine, the first Gryphius, the first Plantin. . . We have, besides these,

\footnotetext{
${ }^{61}$ Marshall W. Swan, "Seneca: Texts and Translations," More Books, XX (1945), 347-54.

62"'Tacitus Collection," Yale University Library Ga. zette, VII (1932), $21 \mathrm{f}$.

WWalter Allen, Jr., "The Yale Manuscript of Tacitus (Codex Budensis Rhenani)." Yale University Library Gazette, XI (1937), 81-86.

${ }^{64}$ Karl Young, "The Uses of Rare Books and Manuscripts," Yale Lniversity Library Gazette, XVI

(1941), 26f. University Library Gazette, XV (1941). 70-77; Downs "Notable Materials Added to American Libraries, 1940-1941," p. 185; Mendell, Tacitus, the Man and His Work (New Haven: Yale University Press, 1957), pp. 321, 384 .
}

eight of the Plantin editions, the first Elzevir, the first edition by Gronovius, and the first by Ernesti. The collection contains over eighty-five different editions previous to 1800 . In addition to these there is the first translation into any language, the German translation of 1535, as well the first Italian and the first English translation, and the first Spanish published in Spain. Interesting for particular reasons are the pirated edition of 1517 (which reprinted the papal edict forbidding its own existence), the rare and handsome Bodoni edition, the beautiful Doves Press Agricola, and the more elaborate but less successful Agricola by Updike at the Merrymount Press."66 Individual items are added to the collection from time to time.

Virgil. The Junius S. Morgan collection of editions of Virgil has long been considered one of the Princeton University Library's "most cherished possessions" and "so outstanding that rarely is there occasion to add a volume of equal worth to the choice and handsome books already on the shelves." 67 In 1930, when the New York Public Library held a bimillennial exhibition of Virgil, no less than 212 of the 325 items shown came from Princeton, and the exhibition's catalog indicates the books which belong to the University. ${ }^{68}$ In recent years the Library has added to this outstanding group such items as the 1529 Wynkyn de Worde edition of the Eclogues ${ }^{69}$ and the Paris edition of the Bucolics (ca. 1498). ${ }^{70}$

In connection with the Virgil bimillennial celebration the Newberry Library in Chicago issued an exhibition catalog of its more notable editions of the poet. Among the items shown were two incunabula editions of the Opera (Nurem-

\footnotetext{
"Mendell, "The Princeps Tacitus," Yale Univer sity Library Gazette, IV (1930), 69.

oz "New and Notable," Princeton University Library Chronicle, VIII (1947), 193.

6s"A Virgilian Exhibition Held at the New York Public Library," Bulletin of the New York Public Library, XXXIV (1930), 491-528.

Library, XXXIV (1930), 491-528; Princeton Univer. sity Library Chronicle, III (1942), 149.

${ }^{0}$ "New and Notable,", loc. cit.
} 
berg: Koberger, 1492; and Venice: Bartholomaeus de Zanis, 1493), and editions from such famous presses as those of Aldus, Elzevir, and Baskerville. A group of translations testifies to the poet's enduring influence. ${ }^{71}$

Horace. If we judge from library resources, one classical author, Horace, has appealed particularly to American book collectors. A half-dozen of them have assembled editions, translations, and criticism of his work, and the fruits of their efforts have become permanent parts of institutional libraries.

The Boston Public Library described its holdings of Horace in connection with the bimillennial anniversary of the poet. It owns two incunabula, the Opera (Florence: Antonio Miscomini, 1482) and the Art Poetica (Paris: Thielman Kerver, 1500). Its seventeenth-century editions were printed in such places as Geneva, London, Amsterdam, and Antwerp. For the eighteenth century one might mention the two-volume Opera published by John Pine, London, 1733-37; the quarto volume of Horace's work printed by Baskerville in Birmingham in 1770 , and the first translation of Horace to appear in America (Philadelphia: Eleazer Oswald, 1786). ${ }^{72}$

At Brown University there is the Foster Collection of Horace containing about six hundred items. The major printers-Aldus, Stephanus, Elzevir, Baskerville, Bodoni, and Pickering - are present, as are humbler items like school texts, paraphrases, and parodies. A fifteenth-century manuscript and three incunabula lend further distinction to the collection. ${ }^{73}$

The University of California (Berkeley) received from the bequest of James

${ }^{71}$ Newberry Library, Virgil, an Exhibition of Early Editions and Facsimiles of Manuscripts Commemo rating the Two-Thousandth Anniversary of His Birth rating the Two-Thousandth Anniversary of His Birth 70 B.C.-1930 A.D. (Chicago, 1930).

72Margaret Munsterberg, "The Bi-Millenial Anniversary of Horace," More Books, X (1935), 245.58.

73 Downs, "Notable Materials Added to American Libraries, 1939-1940," p. 266; Ben C. Clough, "The Foster Collection of Horace," Books at Brown, V (December, 1942), 1.4.

K. Moffitt a Horace collection containing the first dated edition printed in Milan in 1474. Also included are the second printing, undated but probably also $\mathrm{Mi}$ lan, 1474; Gruninger's 1498 illustrated edition as well as the $150 \mathrm{I}$ Aldine. Mr. Moffitt had assembled over 350 editions of Horace, among them four manuscripts of the fourteenth and fifteenth centuries, twenty-four incunabula, and over a hundred editions printed in the sixteenth century. ${ }^{74}$

The Free Library of Philadelphia has received the first of a series of gifts through which Moncure Biddle will present his entire Horace collection. The first group of items included some three hundred volumes of the works of Horace, translations into various languages, commentaries, critical studies, and biographies. They range from the fifteenth century to the present. ${ }^{75}$

In January 1956 Northwestern acquired the Stephen E. Hurley collection of Horace. Consisting of some eighteen hundred Horace editions from 1465 to date, it includes seven incunabula, some sixty sixteenth-century editions, and over one hundred seventeenth-century editions. Particularly notable is the wide range of translations, representing practically every language into which Horace has been translated, which is especially strong in English versions. ${ }^{76}$

One of the outstanding Horace collections is located at Princeton, thanks to the gift of Robert W. Patterson. The Library's holdings include manuscripts and a number of fifteenth-century editions. $^{77}$ A preliminary catalog was issued in 1917.78

The full extent of the Horace collections described above, as well as the location of all specific editions in many libraries, may of course be ascertained by

(Continued on page 486)

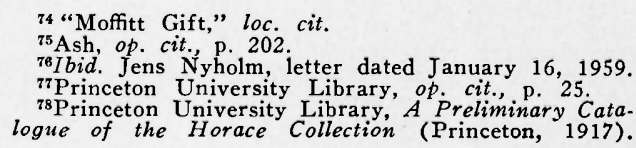




\section{Necrology}

Thomas Marion Iiams died on August 22 at his home in Hamilton, N.Y. He had been in failing health since the dedication

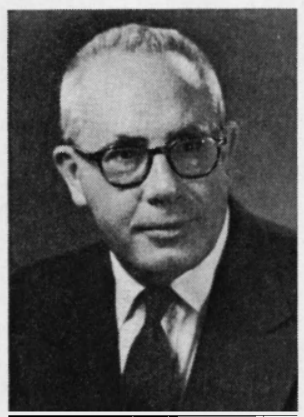

Thomas Marion Iiams of the new library at Colgate, but more noticeably since his return from Washington in June.

One is at a loss to express his thoughts and feelings about a long-time friend in public. Our close friendship came about geographically, though I first met him at the Graduate Library School. One immediately sensed his solid judgment on professional matters but, as time went on, it became evident that here was a rare combination of abilities, very diverse, but also highly developed. Too many people are judged by the quantitative aspects of the positions they hold. Tom Iiams was convinced of the qualitative importance of the smaller institution, and in a short twenty years he brought Colgate University Library to the front rank as.a teaching department of the college. He should be judged by the influence of his library on the institution and of his personality on the profession.

Many will in the future regard the new and magnificent Colgate Library as his monument. Librarians know his personal scholarship. The faculty of Colgate know the value of his scholarship diffused into their work. His staff will remember the leadership he gave them. My own memory is of occasional long hours of good talk and of the frequent telephone calls back and forth on momentarily important items. His aid and advice were always available to his colleagues.-Helmer L. Webb.

Caroline Wenzel, former chief librarian, California Section, California State Library, died March 24.

\section{Library Resources for Classical Studies}

(Continued from page 468)

consulting the check list issued by Mills College in 1938. It should be pointed out that the collections designated "Pr. 7" and "Pr. 15" identify the holdings of Stephen Hurley and James K. Moffitt, now at Northwestern and the University of California respectively. ${ }^{79}$

\section{Conclusion}

In conclusion, we might ask ourselves what this survey of American library resources for classical studies has shown. Three things come to mind.

${ }^{79} Q$ vintes Horativs Flaccvs; Editions in the United States and Canada as They Appear in the Union Catalog of the Library of Congress ([Oakland]: Mills College, 1938).
1. American libraries are certainly equipped to support advanced studies and research in this field.

2. Examination of the literature of library resources reveals, however, that only some of these institutions have published descriptions of or guides to their holdings.

3. Nearly all of the special collections of books by and about individual authors were originally assembled by individual book collectors. Perhaps the love and care lavished on their collections of Horace, Virgil, Persius and the rest is one example of the vitality of the classics in contemporary America! 